\title{
THE EFFECT OF MINIATURE HOME, PICTURES, AND SPATIAL INTELLIGENCES ON STUDENTS' UNDERSTANDING OF GEOMETRIC SPACE CONCEPTS
}

\author{
Dimas Bagus Dwi Setyawan ${ }^{1}$, I Nyoman Sudana Degeng ${ }^{2}$, Nurmida Catherine ${ }^{3}$ \\ ${ }^{1,2,3}$ Universitas PGRI Adi Buana Surabaya, Jalan Dukuh Menanggal XII Surabaya \\ dimasbagus713@gmail.com
}

\begin{abstract}
This study was aimed at determining whether there was an interactive effect of media (miniature home vs. picture) and spatial intelligence on the ability to understand the concept of space. The hypothesis proposed was that there was an effect of using media (miniature home vs. pictures)and spatial intelligence on understanding the spatial concept of the first-grade elementary school students.The subjects were students from an elementary school in Surabaya totaling 66 students assigned into control and experimental classes. The study used a random assigment posttest control group experimental design. The data were collected using tests on spatial intelligence and understanding of the concept of space. The data were analyzed using ANOVA after the tests for homogeneity and normality were done, The results of this study revealed that (1) there was a significant effect of using miniature home, picture, and spatial intelligence on the students 'understanding of spatial concepts, (2) there was a significant influence of the level of spatial intelligence on understanding the concept of space. The group of students who have high spatial intelligences get the learning outcomes of the geometric space better than the group of students who have low spatial intelligences, and (3) there is no interactive influence between learning using miniature home as the media and pictures as the media and the students' spatial intelligences on the subject of geometricspace for the first students of the elementary school.
\end{abstract}

Keywords: Spatial Intelligence, Concept of Geometric Space, Miniature Home Learning Media

\begin{abstract}
Abstrak
Penelitian ini bertujuan untuk menentukan apakah ada efek interaktif dari media (miniatur rumah vs gambar) dan kecerdasan spasial pada kemampuan untuk memahami konsep ruang. Hipotesis yang diajukan adalah ada pengaruh penggunaan media (miniatur rumah vs gambar) dan kecerdasan spasial terhadap pemahaman konsep spasial siswa sekolah dasar kelas satu. Subjek penelitian adalah siswa dari sekolah dasar di Surabaya yang berjumlah 66 siswa yang ditugaskan. ke dalam kelas kontrol dan eksperimen. Penelitian ini menggunakan desain eksperimen kelompok kontrol posttest asigment acak. Data dikumpulkan dengan menggunakan tes kecerdasan spasial dan pemahaman konsep ruang. Data dianalisis menggunakan ANOVA setelah tes untuk homogenitas dan normalitas dilakukan, Hasil penelitian ini mengungkapkan bahwa (1) ada pengaruh yang signifikan menggunakan miniatur rumah, gambar, dan kecerdasan spasial pada pemahaman siswa tentang konsep spasial, (2) ada pengaruh yang signifikan dari tingkat kecerdasan spasial dalam memahami konsep ruang. Kelompok siswa yang memiliki kecerdasan spasial tinggi mendapatkan hasil belajar ruang geometrik lebih baik daripada kelompok siswa yang memiliki kecerdasan spasial rendah, dan (3) tidak ada pengaruh interaktif antara pembelajaran menggunakan rumah miniatur sebagai media dan gambar sebagai media dan kecerdasan spasial siswa pada subjek ruang geometris untuk siswa pertama sekolah dasar.
\end{abstract}

Kata kunci: Intelegensi Spasial, Konsep Ruang, Media Pembelejaran Miniatur Rumah

The importance of learning about place and space for elementary school students, such as blocks, cubes, ovals, rounds and triangles and learning mathematics is inevitable and the learning should be fun for students so that students are not only able to memorize mathematical concepts, but also must be applied to their daily lives, so it is expected that the learning process practiced by the teacher also involves and activates students in the process of finding mathematical concepts. Mathematics learning in elementary schools should therefore able to develop mathematical competencies such as those contained in the mathematics curriculum. Therefore, it is very precise and very wise for students of elementary and junior high schools to learn and understand the nature and types of building this mathematic space. Understanding Mathematical space deals with content or 
volume and can also be called three-dimensional because it has sides, vertices and lines that are mutually limiting, the building side of space is a characteristic of a mathematical space.

Thus learning media is required. Learning media is one tool to convey the message conveyed in learning so that the teaching and learning process is effective (Ariyanti, 2015: 12). The use of media for elementary school students is important since primary school-aged children are included in the concrete operational stages. At the concrete operational stage, the children are able to think systematically about objects and concrete events. Accordingly, they need a medium to solve abstract problems.

Life is surrounded and shaped by geometry (space and surface) so that the learning and teaching of mathematics should be based on and directed towards understanding the spatial aspects around students' life. Studies on geometry learning and teaching in both Indonesia and international level found that the result of geometry learning is not satisfactory yet. These studies show that students' low competence of mathematical spatial visualization is due to the reason that students' inability to visualize three-dimensional objects within two-dimensional one (Susilawati, et. al., 2017).

The term learning is used to show the educational efforts undertaken deliberately, with the goals set before the process is carried out, and its implementation is controllable. Learning media is all that is used to deliver a message and can stimulate the mind, feelings, concerns, and willingness of the students so as to encourage the learning process of deliberate, purposeful, and controlled. Media is an intermediary or a messenger. One of them is applied by the application and use of methods and media, are all things that can be used to deliver a message from the sender to the receiver so that it can stimulate the mind, attention and interest, resulting in the learning process (Harahap \& Surya, 2017).

This research raised questions, they are: 1) whether there are any significant differences in geometric space learning achievement of the first-grade students between the group of students who learned from miniature home and those who learned from pictures?; 2) whether there are any significant differences in geometric learning achievement between the first grade students between the group of students who have high spatial ability and those who have low spatial ability?; 3) whether there is an interaction between learning media type (miniature home and pictures) and spatial ability (high and low) on geometric space learning achievement of the first grade students?

Miniature home according to Webster (1983: 105) is a real form of an object that is shaped in small size so that students can obtain skills through experience, study and observation. Thus, the media as a skill tool that functions as intelligence diggers in the working system of the child's brain.

The benefits of miniature home for teachers are that it serves as a learning medium with the aim that students understand the concept of space, and the teacher is easier to explain to students about the concept of space. Miniatures are used to show parts of space such as beams, cubes and rounds. With the existence of such media students are able to increase the level of cognitive development, in particular students' spatial intelligences (Muthmainah, 2019).

Understanding concept aims to find out the extent to which students receive and understand 
the basic concepts of mathematics that students have received (Olkun, 2013; Raine, 2016). This study focuses on the indicators of understanding concepts as follows.

a. classifying objects according to certain properties of a space concept through miniatures

b. distinguishing examples of space concepts through miniature and pictures

c. restating the concept of three-dimensional space.

In order to make this experience more palatable to students, and in order to engage them, instructors can use pictures to provide the students with the chance of being creative and using their imagination (Krčelić \& Matijević, 2015; Riastuti, 2016)

\section{METHOD}

This research used a random assigment posttest control group experimental design.It involved the randomly assigning subjects between two groups, an experimental or test group and a control. The design allowed the researchers to compare the final posttest results between the two groups, giving them an idea of the overall effectiveness of the intervention or treatment. Figure 1 summarizes the research design.

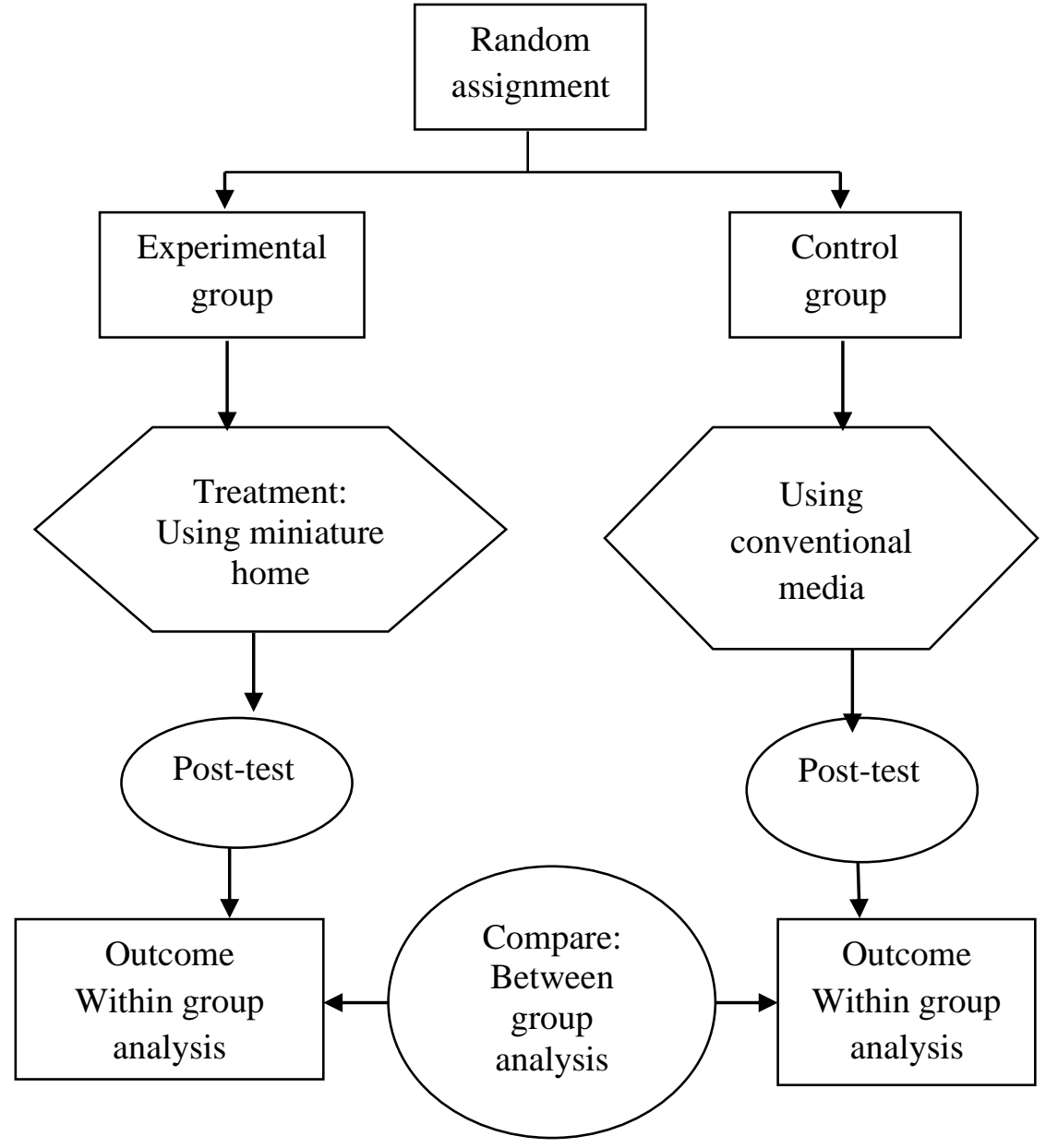

Figure 1. The experimental research design

It was carried out from March to May 2018 at a public elementary school in Surabaya with the subjects of a total of 66 students consisting of Class 1A as the experimental class as many as 34 students, and class 1B is the control class of 32 students. At the end of the study, the research subjects 
The Effect of Miniature Home, Pictures, and Spatial Intelligences on Students' Understanding of Geometric Space Concepts, Dimas Bagus Dwi Setyawan, I Nyoman Sudana Degeng, Nurmida Catherine

were 65 students, as many as 1 student included in the organization because the details for each class are shown in Table 1 as follows. By doing so, the main effect and the interaction effect of all of the treatment variables can be determined.

Table 1.

The distribution of research sample

\begin{tabular}{ccccc}
\hline $\begin{array}{c}\text { Learning } \\
\text { media }\end{array}$ & $\begin{array}{c}\text { Initial } \\
\text { Amount }\end{array}$ & $\begin{array}{c}\text { Initial } \\
\text { Amount }\end{array}$ & $\begin{array}{c}\text { Excluded in } \\
\text { the analysis }\end{array}$ & Remarks \\
\hline Class IA & 34 & 34 & 0 \\
Class IB & 33 & 32 & 1 \\
Total & 67 & 66 & 1 & \\
\hline
\end{tabular}

This research used two types of instrument.They were an instrument for conducting the treatment intervention and an instrument for measuring intervention result (post-test). The first type of instrument was in the form of learning media presentation, whereas the second type of instrument was an instrument to measure the dependent variables as the direct effect of the treatments. The results obtained (through the post-test) would be used as a research analysis unit.

To collect the data, the researchers assigned a treatment, i.e. the use of home miniature to the experimental class (Class IA) and observes the response. The instrument consisted of a learning achievement test with four-option multiple-choice items. The control group- a group receiving no treatment (Class IB) was used to compare the effectiveness of the treatment. The instrument used was a learning achievement test with four-option multiple-choice items. The treatment effect is measured simply as the difference in the posttest scores between the two groups.

The data were analyzed using ANOVA after the tests for homogeneity and normality were done (Ary et al., 2010).All of the test used 5\% level of significance $(\alpha=.05)$. All statistical analyses were done by using SPSS 21 for Windows software (Roesminingsih, 2007).

\section{RESULTS AND DISCUSSION}

This study begins by administering a test to figure out the average score of the students' initial ability score in the miniature home class and the pictures class to provide information on the possibility of differences in the average of class of miniature and class of pictures. It is summarized in Table 2.

\section{Table 2.}

The distribution of research sample

\begin{tabular}{|c|c|c|c|}
\hline Hypotheses & $\mathbf{F}$ & Sig. & $\begin{array}{l}\text { Accepted } \\
\text { /Rejected }\end{array}$ \\
\hline $\begin{array}{l}\text { Ha: } \\
\text { There was a significant difference in the } \\
\text { understanding of the concepts of geometric } \\
\text { space of the students who applied miniature } \\
\text { home in their learning and the ones who }\end{array}$ & 42.83 & .440 & $\begin{array}{l}\mathrm{Ha} \\
\text { accepted } \\
\text { Ho rejected }\end{array}$ \\
\hline
\end{tabular}




\begin{tabular}{|l|l|l|l|}
\hline utilized pictures. & & & \\
\hline $\begin{array}{l}\text { Ho: } \\
\text { There was no significant difference in the } \\
\text { understanding of the concepts of geometric } \\
\text { space of the students who applied miniature } \\
\text { home in their learning and the ones who } \\
\text { utilized pictures. }\end{array}$ & & & \\
\hline $\begin{array}{l}\text { Ha: } \\
\text { There was a significant difference in the } \\
\text { understanding of the concepts of space of the } \\
\text { students who had high spatial intelligences } \\
\text { and the ones who had low spatial } \\
\text { intelligences. }\end{array}$ & 7.603 & .000 & $\begin{array}{l}\text { Ha } \\
\text { accepted } \\
\text { Ho rejected }\end{array}$ \\
\hline $\begin{array}{l}\text { Ho: } \\
\text { There was a significant difference in the } \\
\text { understanding of the concepts of space of the } \\
\text { students who had high spatial intelligences } \\
\text { and the ones who had low spatial } \\
\text { intelligences. }\end{array}$ & & & \\
\hline $\begin{array}{l}\text { Ha: } \\
\text { There was an interaction between the use of } \\
\text { miniature home and pictures on spatial } \\
\text { intelligences. }\end{array}$ & 6.071 & .341 & \\
\hline $\begin{array}{l}\text { Ho: } \\
\text { There was no interaction between the use of } \\
\text { miniature home and pictures on spatial } \\
\text { intelligences. }\end{array}$ & & & \\
\hline
\end{tabular}

The result of the first hypothesis testing as shown in Table 2 indicated that there was a significant difference in the students' understanding concepts of geometric space viewed from the type of learning media (miniature home and pictures) $(\mathrm{F}=42.83 ; \mathrm{p}<.05)$. Based on this result the first working hypothesis $(\mathrm{Ha})$ is accepted, the null hypothesis $(\mathrm{Ho})$ is rejected. The same result was also found in learning achievement of the students with high spatial ability and low spatial ability. The result of analysis as illustrated in Table 2 indicated that there was a significant difference in the students' understanding concepts of geometric space viewed from spatial ability (high and low) (F = $7.603 ; \mathrm{p}<.05)$. Thus the second alternative hypothesis $(\mathrm{Ha})$ is accepted, the null hypothesis $(\mathrm{Ho})$ is rejected.

The result of the third hypothesis testing as summarized in Table 2 showed that there was the effect of interaction between learning media (miniature home and pictures) and spatial ability (high and low) $(\mathrm{F}=6.071 ; \mathrm{p}>.05)$. Based on these results it can be concluded that the third working hypothesis (Ha) is accepted, the null hypothesis (Ho) is rejected. This research finding is in line with the findings of previous studies (Miller et.al., 2013; Sudatha, et.al., 2018). The type of visualization and students' spatial ability seem to be the determining factors in the effectiveness of an instruction. Anglin, et al., (2004) state that the effectiveness of the use of the pictures in instruction depends on how the pictures are applied and the characteristics of the lesson. The visualization which is 
The Effect of Miniature Home, Pictures, and Spatial Intelligences on Students' Understanding of Geometric Space

characterized as the giving of illustrations in the form of real phenomena or as the strengthening of an explanation in the text contributes less in helping the students understand scientific concepts behind the phenomena.

In this research, the result also revealed that the students with spatial ability in the group miniature home and picture presentation was higher than that of the students with low spatial ability in understanding geometric space. The finding is in line with the results in (Amstrong, 2002; Sudjana \% Rifa'i, 2014; Lowrie et al., 2016; Susilawati et. al., 2017) in which spatial ability analysis showed that high spatial ability students in the dynamic group could gain knowledge better of an object in the type of visualization presentation while low spatial ability students did not have cognitive resources to form relations with the type of visualization presentation.

\section{CONCLUSION}

Based on the results previously described, the following conclusions can be drawn: (1) There was a significant influence of the use of learning media (miniature home and pictures) on understanding the concept of space. (2) There was a significant influence of the level of spatial intelligence on understanding the concept of space. The group of students who have high spatial intelligences get the learning outcomes of the geometric space better than the group of students who have low spatial intelligences (Arsyad, 2010; Anjani, 2015). (3) There is no interactive influence between learning using miniature home as the media and pictures as the media and the students' spatial intelligences on the subject of geometricspace for the first students of the elementary school (Muhkan, 2011). (4) There are in fact a number of things that have to be followed up in this research. Some suggestions related to further studies are as follows. (5) The result of the research showed different types of learning media and different levels of the students' spatial ability can influence achievement in geometric space learning. A mixture of types of visualization and different sequences of presentation and their relation to individual characteristics can be explored further in further studies (Fathoni, 2013). (6) Since spatial ability has an effect on instruction with visualization, further studies have to focus on how to design instructional formats that encourage students with low spatial ability, how to involve learners with low spatial ability in helping them processing information and making relations between representations. It becomes an important issue in mathematics instruction (Rositawati, 2017; Anita, 2014). (7) The instruction and instructional material have to consider conceptual ability and spatial ability to support student's understanding through learning media presentation (Sudatha, et. al., 2018). 


\section{REFERENCES}

Amstrong, T. (2002). Sekolah Para Juara: Menerapkan Multiple Intelligence (Translated by Yushi Murtanto). Bandung: Kaifa.

Anglin, G., J., Vaes, H., \& Cunningham, K. L. (2004). Visual representatif and learning: the role of static and animated graphics. In David H. Jonassen (Ed.), Handbook of Research on Educational Communication and Technology (pp. 865-916). Mahwah: Lawrence Erlbaum Associates.

Anitah, S. (2014). Media Pembelajaran. Surakarta: Yuma Pustaka and FKIP UNS.

Anjani, D. A. (2015). Permainan Puzzle Mempengaruhi Perkembangan Kecerdasan Visual-Spatial Anak Usia 4-5 TahunDi Tk Al-Fath Desa Keboan Anom Gedangan Sidoarjo.

Arikunto, S. (2013).Prosedur Penelitian Suatu Pendekatan Praktek, Jakarta: Rineka Cipta.

Arsyad, A. (2010). Media Pembelajaran. Jakarta: PT. Raja Grafindo.

Ary, D., Jacobs, L. C., Sorensen, C., \& Razavieh, A. (2010). Introduction to research in education (8th Ed.). Wadsworth: Cengage Learning.

Briggs, L. (1985). Instructional Media. Pittsburg: AIR.

Fathoni,L. (2013). Profil Kecerdasan Visual-Spasial Siswa Dalam Memahami Gambar Bangun Ruang Yang Tersusun Dari Beberapa Bangun Kubus, JurnalPendidikanUsiaDini.

Gagne, R. and Briggs, L. (2013). Principle of Instructional Design. New York: Holt, Rinnehart and Winston.

Harahap L. W., \& Surya, E. (2017). Development of Learning Media in Mathematics for Students with Special Needs. International Journal of Sciences: Basic and Applied Research (IJSBAR), $33(3), 1-12$.

Krčelić, P. \& Matijević, A. S. (2015). A Picture and a Thousand Words: Visual Tools in ELT. Paper presented at The International Language Conference on The Importance of Learning Professional Foreign Languages for Communication between Cultures.

Lowrie, T., Logan, T., \& Ramful, A. (2016). Spatial Reasoning Influences Students' Performance on Mathematics Tasks. In White, B., Chinnappan, M. \& Trenholm, S. (Eds.). Opening up mathematics education research (Proceedings of the 39th annual conference of the Mathematics Education Research Group of Australasia), 407-414. Adelaide: MERGA.

Miller, D. L., Tichota, K. \& White, J. (2013). Young Children's Authentic Play in a Nature Explore Classroom Supports Foundational Learning: A Single Case Study. Dimensions Educational Research Foundation.

Olkun, S. (2003). Making Connection: Improving Spasial Abilities with Engineering. Drawing Activities, International journal of Mathematics Teaching and Learning. 40 (8).

Sudjana, N., and Rifai, A. (2014). Media Pengajaran. Bandung: Sinar Baru Algendindo.

Raine, V. (2016).A Small Special Needs Class or a Smaller Class at the Beginning of the Educational Path. Journal of Studies in Education, 6 (2). 
The Effect of Miniature Home, Pictures, and Spatial Intelligences on Students' Understanding of Geometric Space Concepts, Dimas Bagus Dwi Setyawan, I Nyoman Sudana Degeng, Nurmida Catherine

Riastuti, N. (2016). Analisis Kecerdasan Spasial Ditinjau Dari Kemampuan Kognitif SiswaPada Materi Lingkaran Siswa Kelas VIII SMP.Retrieved from http://jurnal.fkip.uns.ac.id.

Roesminingsih. (2007). Metode Penelitian Teori dan Aplikasi Jakarta: Bintang.

Rosidah, L. (2014).Peningkatan Kecerdasan Visual Spasial Anak Usia Dini Melalui Permainan Maze. Jurnal Pendidikan Usia Dini, 8 (2). Retrieved on 16 May 2018.

Sadulloh, U. 2013. Pengantar Filsafat Pendidikan. Bandung: Alfabeta.

Susilawati, W., Suryadi, D., \& Dahlan, J. A. (2017). The Improvement of Mathematical Spatial Visualization Ability of Student through Cognitive Conflict. International Electronic Journal of Mathematics Education e-ISSN: 1306-3030. 2017, 12 (2), 155-166. 